\title{
PERFORMANCE OF EXISTING MAIZE SHELLERS IN BANGLADESH
}

\author{
M. M. Alam ${ }^{1 *}$ and M. A. Momin² \\ Department of Farm Power and Machinery, Bangladesh Agricultural University, \\ Mymensingh 2202, Bangladesh
}

\begin{abstract}
This study was conducted to identify the technical and economical performance of the existing models of maize sheller in the country and suggest the best maize sheller models for the farmers during 3 September 2006 to 30 March 2007 in the area of Bogra, Rangpur, Dinajpur, Rajshahi and Jessore. Detail field tests were conducted on seven selected maize sheller models of three categories to assess the comparative performance. Three basic designs of maize sheller models were identified through field survey and secondary information. The models were Spike-pinion (SP) type, Spiral rasp-bar cylinder (SBC) type and Parallel rasp-bar cylinder (PBC) type. The technical performances of the selected maize sheller models were evaluated on the basis of throughput capacity, shelling capacity, cylinder loss, separating loss, broken kernel and shelling efficiency. The shelling capacity and efficiency of Binimoy and Sarker spike-pinion (SP) type models were found about $0.45 \mathrm{ton} / \mathrm{hr}$ and $93 \%$, respectively. Similarly, the shelling capacities and efficiencies of Farida, Rahman and Uttaran spiral rasp-bar cylinder (SBC) models were ranged between 2.8 to 4.0 ton/hr and 93 to $97 \%$, respectively. Farida parallel rasp-bar (PBC) type maize sheller had shown incredible shelling efficiency of about $99 \%$ with almost negligible cylinder $(0.25 \%)$ and separating $(0.25 \%)$ losses along with lowest broken kernel $(2.5 \%)$ percentage. However, the shelling capacity was found comparatively low about 1.9 ton/hr. The shelling costs, benefit-cost ratios and net margins of spiral raspbar cylinder models vary between Tk. 91-97/ton, 1.28-1.37 and Tk78-134/hr, respectively. Among the models Farida (SBC) appeared as the most economic one having lowest shelling cost of Tk. 91/ton with the highest benefit-cost ratio of 1.37 and net margin of Tk. 134/hr (determined at a custom-hire rate of Tk. 7 per $40 \mathrm{~kg}$ of shelled kernel). Comparative economic uses of the selected maize shellers suggest that the use of hand sheller is beneficial up to an annual use of 13 ton. Whereas, Binimoy (SP) and Sarker (SP) models are economic for annual use between 13 and 30 ton, and Farida (SBC), Rahman (SBC) and Uttaran (SBC) models are economic for shelling over 30 ton per annum. Economic analysis suggest that hand sheller could be beneficial for very small farm holdings, Binimoy (SP) and Sarker (SP) models for small farm holdings and Farida (SBC), Rahman (SBC) and Uttaran (SBC) models for medium to large farm holdings and custom-hire service.
\end{abstract}

Key words : Maize sheller, Technical performance, Economic performance

\footnotetext{
1 Professor, ${ }^{2}$ Assistant Professor, Department of Farm Power and Machinery, Bangladesh Agricultural University, Mymensingh 2202, Bangladesh

* Correspondence E-mail:- mmalam.bau@gmail.com
} 


\section{INTRODUCTION}

Maize is the third most important cereal crop in Bangladesh after Rice and Wheat. Since early 1990s maize cropped area has increased at an average rate of $20 \%$ per year to reach $1,24,000$ ha in 2005-06 with an estimated average national yield of 5.7 ton/ha (CIMMYT, 2006). The market demand of maize is steadily increasing especially in poultry and fish feed industries, and the financial return per ha of Rabi season maize is about 2-3 times of wheat and Boro rice. At present, local maize production meets around $40 \%$ of current demand (1.2 million tons per year). By 2010 the production area of maize may reach 2,00,000 ha, producing 1.1 million tons of grain (CIMMYT, 2006).

Shelling of maize refers to freeing the kernels out of the maize cobs. Until recently, shelling of maize was done manually and poses a challenge to maize cultivation due to its slow and painstaking process. In Bangladesh, over $90 \%$ shelling of maize is done by nonmechanized, non-standard shelling devices, resulting high percentage of broken kernels. It causes a lot of wastage and rejections. In recent time, mechanized shelling devices are being manufactured in the country and used at farmers' level. Non-standard shelling devices produce high percentage of broken kernels (often $7-8 \%$ ) and cause a lot of wastage and rejections. Besides, the broken kernels are susceptible to develop aflatoxin, a toxic element potentially dangerous for human as well as animal health. Gradually new mechanized shelling devices are being introduced to the maize growing areas of the country. Few manufacturers such as Rahman, Farida, Uttaran, Sarker, Binimoy, Janata, Mahbub Engineering etc. are producing two basic designs of maize shellers. However, the maize sheller models available in the market are not efficient or cost effective. For obvious reasons, the users of maize shellers are not able to harness the benefits of use mechanical devices. In this context, a detail assessment of technical and financial aspects of the commonly used maize sheller models is of great importance to identify the bestsuited models for Bangladesh condition and to attain maximum benefits out of these mechanical devices. The specific objectives of this study were :

i. To identify the existing models of maize sheller in Bangladesh

ii. To conduct a technical and financial analysis of the most common maize sheller models in Bangladesh.

\section{MATERIALS AND METHODS}

\section{Study areas}

Based on the production of maize, the use of maize shellers and concentration of the manufacturers of maize sheller, five distinct locations or clusters were selected for this study. The locations were Bogra, Rangpur, Dinajpur, Rajshahi and Jessore. The study was conducted during the period of 3 September 2006 to 30 March 2007.

\section{Technical analysis of the selected maize sheller models}

Detail field performance tests were conducted during 16 - 22 October 2006 on seven selected maize sheller models of three categories such as spike-pinion type (Binimoy and 
Sarker models), spiral rasp-bar cylinder type (Rahman, Uttran and Farida models) and parallel rasp-bar cylinder type (Sarker and Farida models) to asses the comparative technical and financial performances.

\section{Calculation procedures for technical parameters}

The technical performance was studied during $16-22$ October 2006. The maize used for the study were harvested from two different plots having moisture contents of $17 \%$ and $21 \%$ wet-basis and the cob-kernel ratio of $1: 3$ and $1: 4$, respectively. The days were sunny and the temperature varied between $25-38^{\circ} \mathrm{C}$ with a relative humidity of around $55 \%$. Same threshing floor, operator, labour and similar operating conditions were carefully maintained during evaluation of the technical performance of the maize sheller models.

\section{Kernel-cob ratio}

Twenty un-shelled cobs were collected and weighed. After shelling manually, the kernels were weighed and subtracted from the total weight, to get cob weight. The kernel-cob ratio was calculated as :

$$
\mathrm{KCR}=\frac{\mathrm{KW}}{\mathrm{CW}}
$$

Where, $\mathrm{KCR}=$ Kernel-cob ratio, $\mathrm{KW}=$ Kernel weight, $\mathrm{kg} ; \mathrm{CW}=\mathrm{Cob}$ weight, $\mathrm{kg}$

\section{Kernel and cob moisture content}

Immediately after shelling, samples of kernel and cob were taken to determine the moisture content. After weighing, the samples were put in an electric oven at $105^{\circ} \mathrm{C}$ temperature for 24 hours and weighed. Moisture content was determined as follows:

$$
\mathrm{MC}=\frac{\mathrm{W}_{\mathrm{w}}-\mathrm{W}_{\mathrm{d}}}{\mathrm{W}_{\mathrm{w}}} \times 100
$$

Where,

$\mathrm{MC}=$ Moisture content in wet basis, $\% ; \mathrm{W}_{\mathrm{w}}=$ Weight of wet kernel or cob, gm; $\mathrm{W}_{\mathrm{d}}=$ Weight of dry kernel or cob, gm.

\section{Shelling capacity}

The weight of kernels (whole and damage) shelled and received per hour at the main kernel outlet is called shelling capacity. At the end of each test, total shelled kernel was collected from the main kernel outlet. The shelling capacity was calculated from the following expression :

$$
\mathrm{SC}=\frac{\mathrm{WK}}{\mathrm{T}} \times 60
$$

Where,

$\mathrm{SC}=$ Shelling capacity, $\mathrm{kg} / \mathrm{hr} ; \mathrm{WK}=$ Weight of total output kernel, $\mathrm{kg} ; \mathrm{T}=$ Recorded time, minute. 


\section{Throughput capacity}

The weight of whole cob (kernel and cob) shelled per hour is called throughput capacity. The throughput capacity was calculated from the following expression :

$$
\mathrm{TC}=\frac{\mathrm{WWC}}{\mathrm{T}} \times 60
$$

Where,

$\mathrm{TC}=$ Throughput capacity, $\mathrm{kg} / \mathrm{hr} ; \mathrm{WWC}=$ Weight of whole cob (kernel and cob), $\mathrm{kg}$; $\mathrm{T}=$ Recorded time, minute.

\section{Cylinder loss}

After shelling, the whole kernel still attached to the cob is called cylinder loss. The percent of cylinder loss was calculated as:

$$
\mathrm{CL}=\frac{\mathrm{WCK}}{\mathrm{WK}+\mathrm{WCK}+\mathrm{WSK}+\mathrm{WPK}} \times 100
$$

Where, $\mathrm{CL}=$ Cylinder loss, $\%$; WCK $=$ Weight of cylinder loss kernel, $\mathrm{kg}$; WK $=$ Weight of output kernel, $\mathrm{kg}$; WSK = Weight of separating loss kernel, kg; WPK= Weight of spilled loss kernel, kg.

\section{Separating loss}

The loose kernels collected from shelled cob is called separating loss. The percentage of separating loss was calculated as:

$$
\mathrm{SL}=\frac{\mathrm{WSK}}{\mathrm{WK}+\mathrm{WCK}+\mathrm{WSK}+\mathrm{WPK}} \times 100
$$

Where, $\mathrm{SL}=$ Separating loss, $\%$.

\section{Spilled kernel loss}

During shelling, the shelled kernel cobs were deposited at a distance in front of the sheller. After collecting the shelled kernel as net output, the kernels still scattered at a certain distance from the sheller was termed as spilled kernel. The percent of spilled kernel loss was calculated as:

$$
\mathrm{PL}=\frac{\mathrm{WPK}}{\mathrm{WK}+\mathrm{WCK}+\mathrm{WSK}+\mathrm{WPK}} \times 100
$$

Where, $\mathrm{PL}=$ Spilled kernel loss, $\%$.

\section{Shelling efficiency}

The net shelled kernel received at with respect to total kernel input, expressed as percent by weight, was termed as shelling efficiency. The shelling efficiency was calculated from the following expression:

$$
\mathrm{TE}=\frac{\mathrm{WK}+\text { All outlets }}{\mathrm{WK}+\mathrm{WCK}+\mathrm{WSK}+\mathrm{WPK}} \times 100
$$

Where, SE = Shelling efficiency, $\%$. 


\section{Broken Kernel}

After shelling broken kernels were collected and weighted, and calculated in percentage in terms of gross output kernels as :

Where,

$$
\mathrm{CL}=\frac{\mathrm{BKW}}{\mathrm{GOK}} \times 100
$$

$\mathrm{BK}=$ Broken kernel, \%; BKW = Broken kernel weight, kg; GOK = Output kernel, kg.

\section{Calculation procedures for economic parameters}

\section{Fixed costs}

Fixed costs are independent of use. Fixed costs include depreciation (D), interest on the machinery investment (I), taxes (T), insurance (In) and shelter (S). A straight-line depreciation was used for calculation of fixed cost

$$
\text { a) Annual depreciation, } D=\frac{P-S}{L}
$$
Where,

$D=$ depreciation, Tk./yr.; $P=$ purchase price of maize sheller, Tk.; $S=$ salvage value, Tk.; $L=$ life of maize sheller, year.

b) Interest on investment, $I=\frac{P+S}{2} \times i$

Where, $i=$ rate of interest.

Annual fixed cost (Tk/yr), $F C=(a+b)$

$$
\text { Fixed cost }(\mathrm{Tk} / \mathrm{hr})=\frac{\mathrm{Fe}}{\text { Sheller use }(\mathrm{hr} / \mathrm{yr})}
$$

\section{Variable cost}

Operating cost of a maize sheller is reflected by the cost of fuel, lubrication, daily service, power and labour used by the power source and the sheller. These costs increase with increased use of the machine, and vary largely in direct proportion to hours or days of use per year.

a) Labour cost per hour, $\mathrm{L}=$ No. of labour $x$ Rate of labour (Tk/ hr)

b) Fuel cost per hour, F = Price of fuel (Tk/liter) $\times$ Fuel consumption (liter/hr)

c) Lubricant/Oil cost per hour, $\mathrm{O}=$ Price of oil (Tk/liter) x Oil used (liter/hr)

d) Repair and maintenance cost per hour, $\mathrm{R} \& \mathrm{M}=$ Annual repair \& maintenance cost / Annual operating hrs

e) Cost of power source, $\mathrm{E}=\mathrm{Tk} / \mathrm{hr}$.

Variable cost $=(a+b+c+d+e)$

\section{Operating cost of maize sheller}

The operating cost of maize sheller was calculated as follows:

$$
\mathrm{C}_{\mathrm{oc}}=\text { Fixed cost }(\mathrm{Tk} / \mathrm{hr})+\text { Variable cost }(\mathrm{Tk} / \mathrm{hr})
$$


Where,

$C_{o c}=$ operating cost, Tk. $/ \mathrm{hr} ; C_{o c}(\mathrm{Tk} /$ ton $)=$ operating cost $(\mathrm{Tk} . / \mathrm{hr}) /$ shelling capacity (ton/hr)

\section{Cost of shelling}

The cost of shelling, $\mathrm{C}_{\mathrm{kg}}$ was calculated by using the following formula:

$$
C_{k g}=C_{p r}+C_{s e}+C_{o c}
$$

Where,

$C_{k g}=$ cost of shelling in Tk./ton; $C_{p r}=$ cost of processing in Tk./ton; $C_{s e}=$ cost of separating in Tk./ton; $C_{o c}=$ operating cost of sheller, Tk./ton.

Cost items are shown in Table 1.

Table 1. Cost item used for calculation

\begin{tabular}{l|c|c|c|c|c|c|c}
\hline \multirow{2}{*}{ Cost item } & \multicolumn{7}{c}{ Data collected and value assumed } \\
\cline { 2 - 8 } & $\begin{array}{c}\text { Binimoy } \\
\text { (SP) }\end{array}$ & $\begin{array}{c}\text { Sarker } \\
\text { (SP) }\end{array}$ & $\begin{array}{c}\text { Sarker } \\
\text { (PBC) }\end{array}$ & $\begin{array}{c}\text { Rahman } \\
\text { (SBC) }\end{array}$ & $\begin{array}{c}\text { Uttaran } \\
\text { (SBC) }\end{array}$ & $\begin{array}{c}\text { Farida } \\
\text { (SBC) }\end{array}$ & $\begin{array}{c}\text { Farida } \\
\text { (PBC) }\end{array}$ \\
\hline (a) Bank interest, I (\%) & 11 & 11 & 11 & 11 & 11 & 11 & 11 \\
(b) Slvage value, S (\% of purchase & 10 & 10 & 10 & 10 & 10 & 10 & 10 \\
$\quad$ price) & & & & & & & \\
(c) Repair and maintenance cost, & 0.46 & 0.46 & 0.46 & 0.46 & 0.46 & 0.46 & 0.46 \\
$\quad$ Tk/hr & & & & & & & \\
(d) Purchase price, Tk. & 7000 & 8000 & 12000 & 14000 & 21000 & 18000 & 16000 \\
(e) Life & 6 & 6 & 10 & 10 & 10 & 10 & 10 \\
(f) Number of labour requirement & & & & & & & \\
$\quad$ Machine operation & 2 & 2 & 5 & 5 & 5 & 5 & 5 \\
$\quad \begin{array}{l}\text { Processing } \\
\quad \text { Separating }\end{array}$ & 4 & 4 & 5 & 5 & 5 & 5 & 5 \\
(g) Rate of labour, Tk/day (8 hrs) & 70 & 70 & 70 & 70 & 70 & 70 & 70 \\
(h) Fuel cost, Tk/hr & 8.5 & 8.5 & 8.5 & 8.5 & 8.5 & 8.5 & 8.5 \\
(i) Oil cost, Tk/hr & 0.44 & 0.44 & 0.44 & 0.44 & 0.44 & 0.44 & 0.44 \\
(j) Engine fixed cost, Tk/hr & 0.95 & 0.95 & 1.44 & 1.44 & 1.25 & 1.25 & 1.25 \\
(k) Sheller hiring rate, Tk/40 kg of & 7 & 7 & 5 & 5 & 5 & 5 & 5 \\
$\quad$ shelled kernel & & & & & & & \\
(l) Sheller use, hrs/yr & 900 & 900 & 900 & 900 & 900 & 900 & 900 \\
\hline
\end{tabular}

\section{Break-even use}

The following formula was used to estimate the appropriate "break-even" use of selected maize shellers :

Break-even use $($ ton $)=$ Fixed cost of the sheller for entire economic life $(\mathrm{Tk}) /\{$ Hiring rate of the sheller (Tk/ton) - Variable cost of the sheller (Tk/ton)\} 
Where,

Fixed cost of the sheller for entire economic life (Tk.) = Annual fixed cost of the sheller (Tk./yr) x Economic life of the sheller (yr)

\section{Benefit cost ratio $(B / C)$}

Benefit cost ratio was defined as the ratio of gross revenue to shelling cost (expressed either in \% or in annual worth).

$$
\mathrm{B} / \mathrm{C} \text { ratio }=\text { Gross revenue }(\mathrm{Tk} . / \mathrm{hr}) / \text { Shelling cost }(\mathrm{Tk} . / \mathrm{hr})
$$

\section{Calculation for gross margin (GM) and net margin (NM)}

The gross margin was calculated as gross output less total variable costs and net margin (NM) was calculated as gross margin (GM) less fixed costs (FC).

Gross revenue $=[$ Units $] \times[$ Hiring rate per unit $]$

Gross Margin $=[$ Gross output $]-[$ Total variable cost $]$

Net Margin $=[$ Gross Margin $]-[$ Fixed costs $]$

\section{Partial budget calculation}

\begin{tabular}{l|l}
\hline Costs of change & Benefits of change \\
\hline GM lost : & Extra GM : \\
Expected GM of the existing system & Expected GM of the alternative system \\
Extra fixed costs : & Fixed costs saved : \\
Estimated new fixed cost & Estimated reduction of fixed costs \\
\hline Total costs $(\mathrm{X})$ & Total benefits $(\mathrm{Y})$ \\
\hline Net gain $(\mathrm{Y}>\mathrm{X})$ & Net loss $(\mathrm{X}>\mathrm{Y})$ \\
\hline
\end{tabular}

\section{RESULTS AND DISCUSSION}

\section{Existing models of maize shellers}

Three basic designs of maize sheller models were identified through field survey and secondary information. The models were Spike-pinion (SP) type, Spiral rasp-bar cylinder (SBC) type and Parallel rasp-bar cylinder (PBC) type.

\section{Spike-pinion (SP) type models}

In Spike-pinion (SP) type maize sheller the cobs are fed into an opening bounded by a rotating fluted pinion, a rotating spiked disc and a spring pressure plate (Fig. 1). The opposite direction rotation of the fluted pinion and the spiked disc remove the kernels and left the cobs undamaged. The spring pressure plate is adjustable and controls the opening for the cobs according to their sizes. 


\section{Spiral rasp-bar cylinder (SBC) type models}

Spiral rasp-bar cylinder (SBC) consists of a cylinder with longitudinal bars and spiral flutes at one end, which turns inside a cage (Fig. 2). The cobs are fed to the spiral flutes, which feed them through the cage and shell the kernels by rolling and crushing between cylinder bars and the cage. The cobs are usually broken down into three to four pieces.
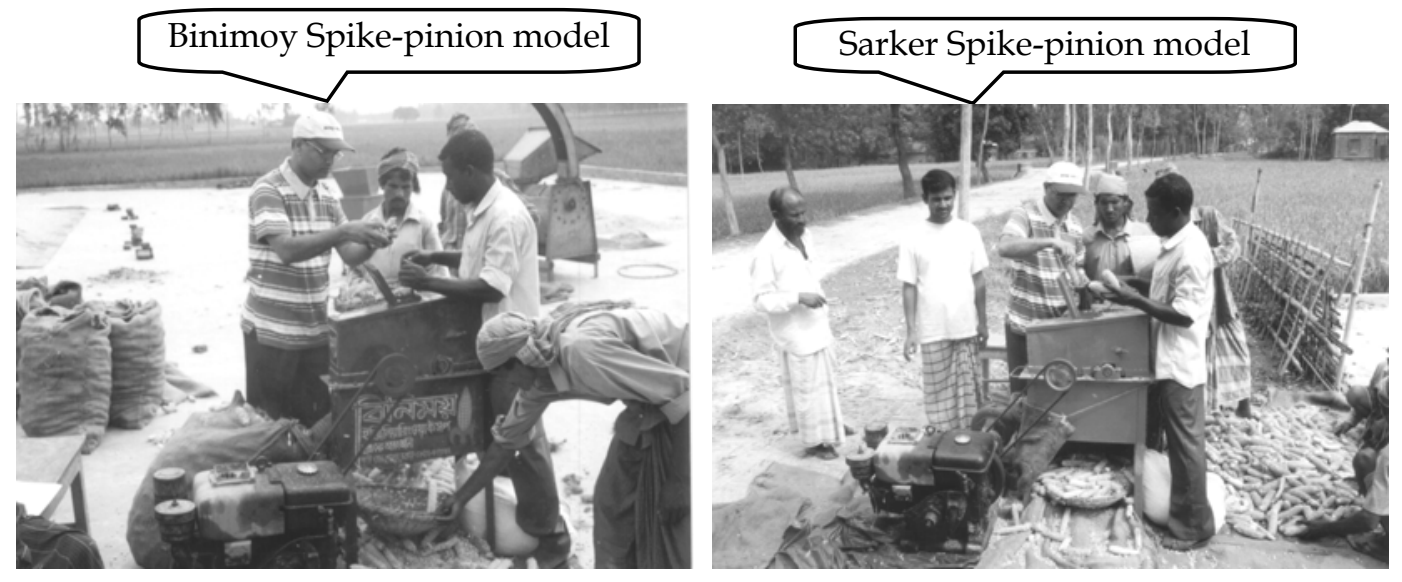

Fig. 1. Spike-pinion type maize shellers

\section{Parallel rasp-bar cylinder (PBC) type models}

Parallel rasp-bar cylinder (PBC) consists of a cylinder having parallel rasp bars and open grate concave. The cobs are fed through the concave and the cylinder, and shell the kernels by rolling and crushing (Fig. 3). The cobs are broken down into smaller pieces.

\section{Technical performance of selected maize sheller models}

The technical performances of seven selected maize sheller models were evaluated on the basis of throughput capacity, shelling capacity, cylinder loss, separating loss, broken kernel and shelling efficiency (Table 2).

The technical performances of Binimoy and Sarker spike-pinion type models shellers were almost similar and satisfactory except the cylinder loss and broken kernel percent were little bit high (about $6 \%$ and 5\%, respectively). This was because of the higher moisture content (21\% wet basis) of cobs used for shelling. The shelling efficiency of these models was about $93 \%$ (Table 2). Depending on the shelling capacity (about $0.45 \mathrm{ton} / \mathrm{hr}$ ) these models were found suitable for small farm holdings.

The technical performances of Farida (SBC) and Rahman (SBC) models were found slightly better than the Uttaran (SBC) model. The cylinder loss and broken kernel percent were slightly higher (about 5 and 7.5\%, respectively) in Uttaran (SBC) model (Table 2). This was because of the workmanship and adjustment made by the operator during operation. The shelling efficiency of Uttaran (SBC) model was found about 93\%, which was slightly lower compared to Rahman (SBC) and Farida (SBC) models (about 97\%). 
However, the technical performances of these sheller models were found satisfactory. The shelling capacities of these models were quite high (in the range of 2.8 to $4.0 \mathrm{ton} / \mathrm{hr}$ ) and suitable for large farm holdings and custom-hire service.
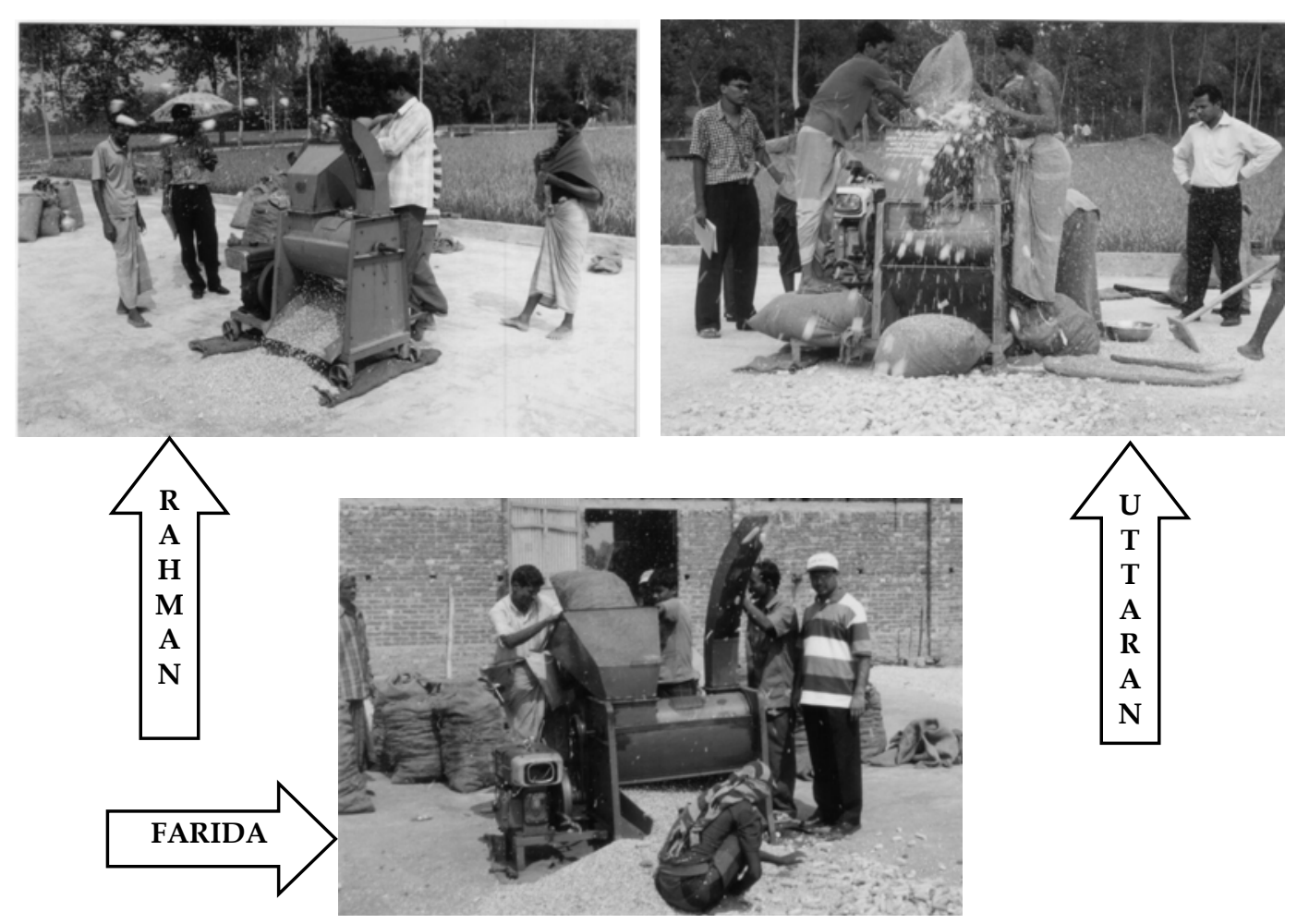

Fig. 2. Spiral rasp-bar cylinder type maize shellers
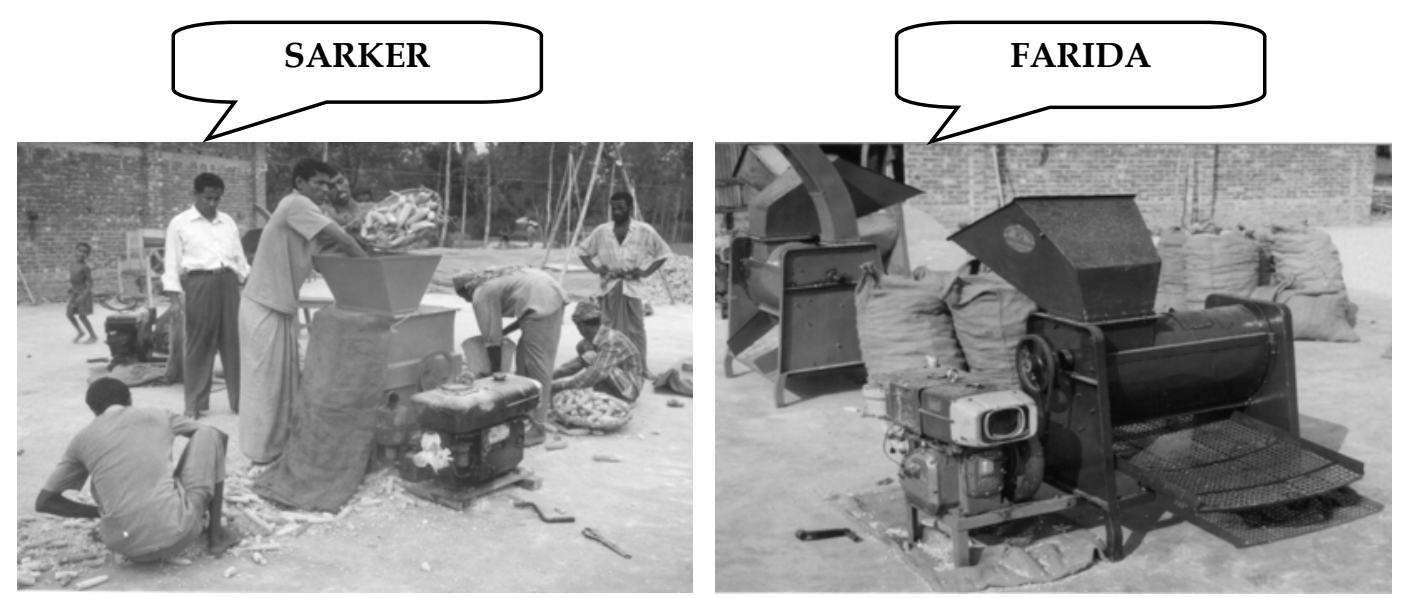

Fig. 3. Parallel rasp-bar cylinder type maize shellers 
The shelling capacity of Sarkar (PBC) models was found about 1.72 ton/hr which was quite low compared to similar size of Sarkar spiral rasp-bar cylinder (Table 2). The cylinder loss, separating loss and broken kernel percentage were comparatively higher than similar size spiral rasp-bar cylinder models (5.14, 1.92 and 5.5\%, respectively). Consequently, the shelling efficiency (about 93\%) was the lowest among similar size shellers. Before marketing, this model needs few design improvements.

Table 2. Technical parameters of selected maize sheller models

\begin{tabular}{l|c|c|c|c|c|c|c}
\hline \multicolumn{1}{c|}{ Model } & $\begin{array}{c}\text { Cylinder } \\
\text { speed } \\
(\mathrm{rpm})\end{array}$ & $\begin{array}{c}\text { Throughput } \\
\text { capacity } \\
(\mathrm{kg} / \mathrm{hr})\end{array}$ & $\begin{array}{c}\text { Shelling } \\
\text { capacity } \\
(\mathrm{kg} / \mathrm{hr})\end{array}$ & $\begin{array}{c}\text { Cylinder } \\
\text { loss }(\%)\end{array}$ & $\begin{array}{c}\text { Separating } \\
\text { loss }(\%)\end{array}$ & $\begin{array}{c}\text { Broken } \\
\text { kernel (\%) }\end{array}$ & $\begin{array}{c}\text { Shelling } \\
\text { efficiency } \\
(\%)\end{array}$ \\
\hline Binimoy (SP) & 550 & 655 & 458 & 5.85 & 1.3 & 3.5 & 92.82 \\
Sarker (SP) & 570 & 640 & 444 & 5.80 & 1.58 & 5 & 92.53 \\
Rahman (SBC) & 1240 & 4800 & 3252 & 1.53 & 1.72 & 2.5 & 96.75 \\
Uttaran (SBC) & 1350 & 4341 & 2838 & 4.76 & 1.87 & 7.5 & 93.37 \\
Farida (SBC) & 850 & 5142 & 4007 & 1.72 & 0.97 & 2.5 & 97.30 \\
Sarker (PBC) & 500 & 2400 & 1720 & 5.14 & 1.92 & 5.5 & 92.93 \\
Farida (PBC) & 710 & 2400 & 1896 & 0.25 & 0.25 & 2.5 & 99.50 \\
\hline
\end{tabular}

The maize sheller of Farida (PBC) had an incredible shelling efficiency of about $99 \%$ with almost negligible cylinder $(0.25 \%)$ and separating $(0.25 \%)$ losses along with lowest broken kernel $(2.5 \%)$ percentage (Table 2$)$. However, the shelling capacity was comparatively low about 1.9 ton/hr. Despite best performance in terms of shelling efficiency, reduction of losses and broken kernel percentage the maize sheller needs few minor modifications.

\section{Recommended operating speed of the maize shellers}

In this study, depending on the shelling capacity, shelling efficiency, cylinder loss and broken kernel percentage optimum range of cylinder speeds of the models were determined and recommended for the operators and users. The recommended range of operating speeds of Binimoy (SP), Sarker (SP), Farida (SBC), Rahman (SBC) and Uttaran (SBC) models were 600-650, 550-600, 800-850, 1200-1250 and 1300-1350 rpm, respectively (Fig. 4 to 11).

Most common economic parameters such as operating cost of sheller, processing cost of kernels and cobs, cost of shelling, gross revenue, benefit-cost ratio, gross margin and net margin of selected maize shellers were determined and presented in Table 3.

\section{Economic parameters of selected maize sheller models}

The shelling cost comprises of machine operating cost and cost of processing of shelled and unshelled kernels (required manual labour for processing and manual shelling of the kernels from unshelled cobs). The cost of shelling of spike-pinion (SP) type models was about Tk. 143/ton of which cost of machine operation and manual processing were Tk. 66/ton and Tk. 77/ton, respectively (Table 3). With a custom-hire rate of Tk. 7 per $40 \mathrm{~kg}$ of shelled kernel the benefit-cost ratio of the models was found about 1.23 with a slim net 
benefit of Tk. 15/hr. Thus, the models appeared as only be owned by individual farmers or custom-hire service providers operating in relatively low area coverage by maize.
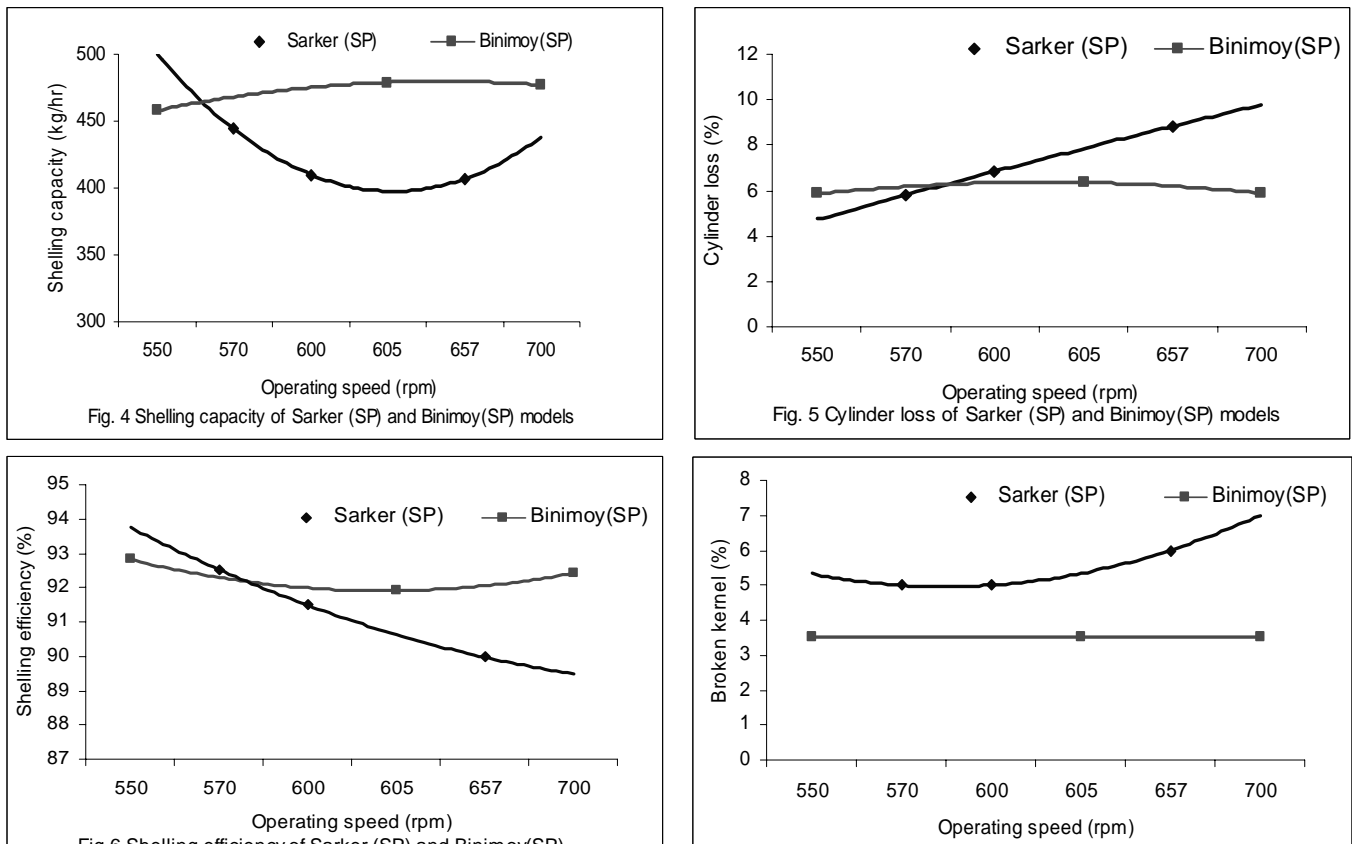

Fig.6 Shelling efficiency of Sarker (SP) and Binimoy(SP) models

Fig. 7 Broken kernel of Sarker (SP) and Binimoy(SP) models

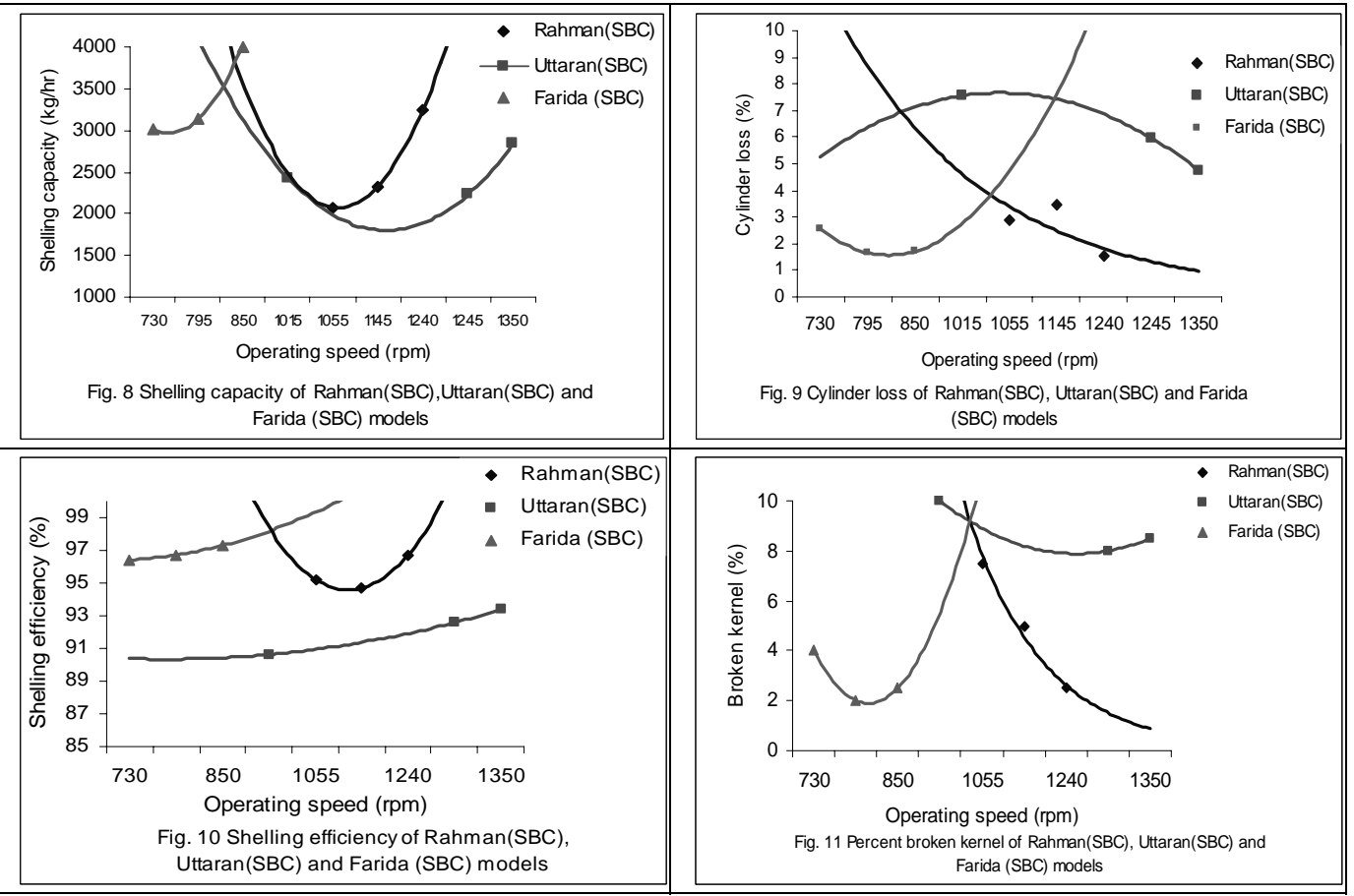


Among the spiral rasp-bar cylinder models the shelling cost of Farida (SBC) model appeared as the lowest about Tk. 91/ton with the highest benefit-cost ratio of 1.37 and net margin of Tk. 134/hr (determined at a custom-hire rate of Tk. 7 per $40 \mathrm{~kg}$ of shelled kernel). The shelling cost, benefit-cost ratio and net margin of Rahman (SBC) model were found about Tk. 95/ton, 1.32, Tk. 99/hr, respectively and Uttaran (SBC) model were found about Tk. 97/ton, 1.28 and Tk.78/hr, respectively (Table 3). These differences in economic performance depend mostly on the size of the sheller models. A slightly larger size of latter models might provide similar net margins as Farida (SBC) model. Depending on economic return, these models were found suitable for large farm holdings and custom-hire service providers of major maize growing regions.

Table 3. Economic parameters of selected maize shellers

\begin{tabular}{l|c|c|c|c|c|c|c|c}
\hline \multicolumn{1}{c|}{ Model } & $\begin{array}{c}\text { Machine } \\
\text { operating } \\
\text { cost } \\
(\mathrm{Tk} / \text { ton })\end{array}$ & $\begin{array}{c}\text { Total } \\
\text { processing } \\
\text { cost } \\
\text { (Tk/ton) }\end{array}$ & $\begin{array}{c}\text { Shelling } \\
\text { cost } \\
(\mathrm{Tk} / \text { ton })\end{array}$ & $\begin{array}{c}\text { Shelling } \\
\text { cost } \\
(\mathrm{Tk} / \mathrm{hr})\end{array}$ & $\begin{array}{c}\text { Gross } \\
\text { revenue } \\
(\mathrm{Tk} / \mathrm{hr})\end{array}$ & $\begin{array}{c}\text { Benefit- } \\
\text { cost } \\
\text { ratio }\end{array}$ & $\begin{array}{c}\text { Gross } \\
\text { margin } \\
(\mathrm{Tk} / \mathrm{hr})\end{array}$ & $\begin{array}{c}\text { Net } \\
\text { margin } \\
(\mathrm{Tk} / \mathrm{hr})\end{array}$ \\
\hline Hand sheller & 160.00 & 77 & 237.00 & 18.92 & 10 & 0.54 & -8.66 & -8.73 \\
Binimoy (SP) & 65.09 & 77 & 142.09 & 65.08 & 57.25 & 0.88 & -4.92 & -7.83 \\
& & & & & $(80.15)^{*}$ & $(1.23)^{*}$ & $(17.98)^{*}$ & $(15.07)^{*}$ \\
Sarker (SP) & 66.46 & 77 & 143.46 & 63.70 & 55.50 & 0.87 & -5.59 & -8.20 \\
& & & & & $(77.70)^{*}$ & $(1.22)^{*}$ & $(16.61)^{*}$ & $(14.00)^{*}$ \\
Sarker (PBC) & 33.13 & 77 & 110.13 & 189.42 & 215.00 & 1.14 & 29.41 & 25.57 \\
Rahman (SBC) & 17.59 & 77 & 94.59 & 307.61 & 406.50 & 1.32 & 102.95 & 98.90 \\
Uttaran (SBC) & 20.21 & 77 & 97.21 & 275.88 & 354.75 & 1.28 & 83.07 & 77.85 \\
Farida (SBC) & 14.44 & 77 & 91.44 & 366.40 & 500.88 & 1.37 & 139.19 & 134.47 \\
Farida (PBC) & 30.35 & 56 & 86.35 & 163.72 & 237.00 & 1.45 & 77.67 & 72.31 \\
\hline
\end{tabular}

*Shelling rate: At Tk. 7 per $40 \mathrm{~kg}$

The cost of shelling among all spiral and parallel rasp-bar cylinder models Farida (PBC) model was the lowest about Tk. 86/ton with the highest benefit-cost ratio of 1.45 (Table 3). This was because the cylinder and separating losses of this model were almost negligible and no need for manual shelling of unshelled kernels from the cobs. The shelling capacity of existing model was almost half of the Farida (SBC) model because of smaller in size. A larger size Farida (PBC) model may provide much higher net return compared to other models of maize sheller.

\section{Substitution proposition among selected maize shellers}

The gross margin and fixed cost data of selected maize sheller models were used in partial budget format and substitution propositions are presented in Table 4 .

The table revealed that the substitution propositions of hand sheller by all selected sheller models were ended with net gains i.e. each selected maize sheller was found economically superior over hand sheller. The substitution proposition among the selected maize sheller models indicated that Farida (SBC) model registered net gain over other sheller models and appeared as the most impressive one. 
Table 4. Substitution proposition of selected maize shellers by partial budgeting

\begin{tabular}{|c|c|c|c|c|c|c|c|}
\hline & Binimoy-SP & Sarker-SP & Sarker-PBC & Rahman-SBC & Uttaran-SBC & Farida-SBC & Farida-PBC \\
\hline Hand sheller & $\begin{array}{l}\text { Net gain } \\
\text { Tk. } 0.78 / \mathrm{hr}\end{array}$ & $\begin{array}{l}\text { Net gain } \\
\text { Tk.0.53/hr }\end{array}$ & $\begin{array}{c}\text { Net gain } \\
\text { Tk.34.08/hr }\end{array}$ & $\begin{array}{c}\text { Net gain } \\
\text { Tk.107.63/hr }\end{array}$ & $\begin{array}{c}\text { Net gain } \\
\text { Tk.86.58/hr }\end{array}$ & $\begin{array}{c}\text { Net gain } \\
\text { Tk. } 143.20 / \mathrm{hr}\end{array}$ & $\begin{array}{c}\text { Net gain } \\
\text { Tk. } 77.74 / \mathrm{hr}\end{array}$ \\
\hline Binimoy-SP & & $\begin{array}{l}\text { Net loss } \\
\text { Tk.0.37/hr }\end{array}$ & $\begin{array}{l}\text { Net gain } \\
\text { Tk.33.40/hr }\end{array}$ & $\begin{array}{c}\text { Net gain } \\
\text { Tk.106.72/hr }\end{array}$ & $\begin{array}{c}\text { Net gain } \\
\text { Tk.85.68/hr }\end{array}$ & $\begin{array}{c}\text { Net gain } \\
\text { Tk. } 142.29 / \mathrm{hr}\end{array}$ & $\begin{array}{l}\text { Net gain } \\
\text { Tk. } 80.12 / \mathrm{hr}\end{array}$ \\
\hline Sarker-SP & & & $\begin{array}{l}\text { Net gain } \\
\text { Tk.33.68/hr }\end{array}$ & $\begin{array}{c}\text { Net gain } \\
\text { Tk.107.09/hr }\end{array}$ & $\begin{array}{c}\text { Net gain } \\
\text { Tk.86.05/hr }\end{array}$ & $\begin{array}{c}\text { Net gain } \\
\text { Tk. } 144.66 / \mathrm{hr}\end{array}$ & $\begin{array}{l}\text { Net gain } \\
\text { Tk. } 80.35 / \mathrm{hr}\end{array}$ \\
\hline Sarker-PBC & & & & $\begin{array}{l}\text { Net gain } \\
\text { Tk.73.33/hr }\end{array}$ & $\begin{array}{c}\text { Net gain } \\
\text { Tk.52.28/hr }\end{array}$ & $\begin{array}{c}\text { Net gain } \\
\text { Tk. } 108.90 / \mathrm{hr}\end{array}$ & $\begin{array}{l}\text { Net gain } \\
\text { Tk.46.74/hr }\end{array}$ \\
\hline Rahman-SBC & & & & & $\begin{array}{c}\text { Net loss } \\
\text { Tk.21.04/hr }\end{array}$ & $\begin{array}{l}\text { Net gain } \\
\text { Tk. } 35.57 / \mathrm{hr}\end{array}$ & $\begin{array}{l}\text { Net loss } \\
\text { Tk. 26.58/hr }\end{array}$ \\
\hline Uttaran-SBC & & & & & & $\begin{array}{l}\text { Net gain } \\
\text { Tk. 56.61/hr }\end{array}$ & $\begin{array}{l}\text { Net loss } \\
\text { Tk. 5.54/hr }\end{array}$ \\
\hline Farida-SBC & & & & & & & $\begin{array}{c}\text { Net loss } \\
\text { Tk. 62.15/hr }\end{array}$ \\
\hline
\end{tabular}

Considering various economic indicators as appeared in the previous sections Farida (SBC), Rahman (SBC), Uttaran (SBC) and Farida (PBC) maize sheller models could be recommended for large farm holdings and custom-hire service.

\section{Economic use of selected maize shellers}

Comparative economic use of the selected maize shellers is shown in Fig. 12. The figure showed that the use of hand sheller was beneficial up to an annual use of 13 ton, perhaps, time for shelling was not be limited by maize harvesting season. Whereas, Binimoy (SP) and Sarker (SP) models were found economic for annual use between 13 and 30 ton, and Farida (SBC), Rahman (SBC) and Uttaran (SBC) models were found economic for shelling over 30 ton per annum.

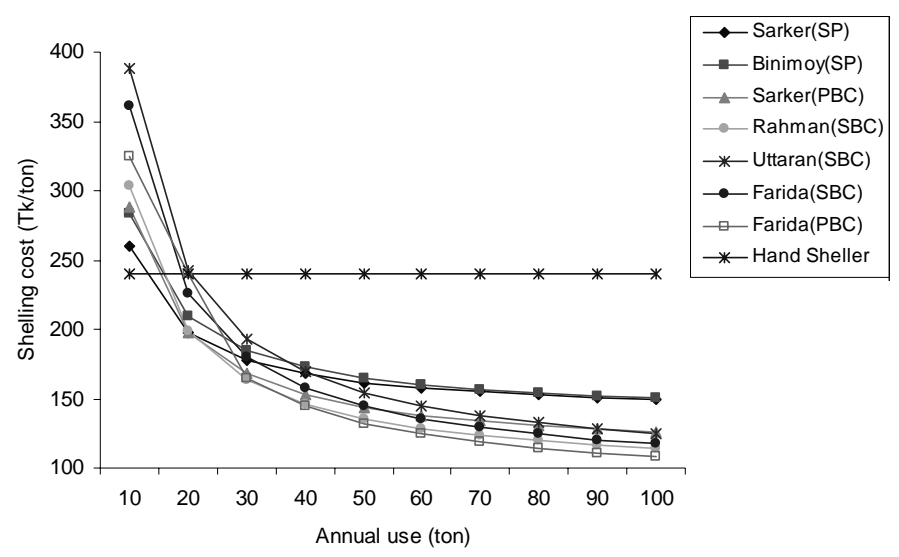

Fig. 12 Economic use of selected Maize shellers

\section{Break-even use of selected maize shellers}

Break-even use of a machine indicates no-profit no-loss situation. Above which the machine use can be considered as net gain. The break-even use of a maize sheller 
depends on its capacity of shelling, power requirement, labour requirement and other charges. The break-even uses of Hand sheller - upto 13 ton/yr Binimoy (SP), Sarker (SP), Rahman (SBC), Uttaran (SBC), Farida (SBC), Sarker (PBC) and Farida (PBC) were found 78 ton (170 hrs), 91 ton (204 hrs), 195 ton (60 hrs), 277 ton (98 hrs), 243 ton (61 hrs), 194 ton (113 hrs) and 249 ton (131 hrs), respectively. Among the maize shellers, Farida (SBC) and Rahman (SBC) models recover its investment within 8 to 10 days of operation time. Rest of its life the maize shellers will be running on net profit. Even the maize shellers having highest break-even use can be run profitably less than a month's use. The study also revealed that in intensely maize growing areas most custom-hire service providers hiredout their shellers more than 90 days a year. This indicates that the selected maize shellers have extremely good business opportunity for small entrepreneurs and individual farmers.

\section{CONCLUSIONS}

The following conclusions are made on the basis of detail field test of commonly used maize sheller models and field survey involving maize sheller users, custom-hire service providers and manufacturers :

- At present, there are three basic designs of mechanized maize sheller models exist in the country. They are Spike-pinion (SP) type, Spiral rasp-bar cylinder (SBC) type and Parallel rasp-bar cylinder (PBC) type.

- The design of Binimoy (SP) and Sarker (SP) models is same and technical performances are almost similar and satisfactory. Based on the shelling capacity these models are suitable for small farm holdings. The design of Farida (SBC), Rahman (SBC) and Uttaran (SBC) models is same, except the size. The technical performances of Farida (SBC) and Rahman (SBC) models are slightly better than the Uttaran (SBC) model. This is because of the workmanship and adjustment made by the operator during operation. The technical performances of these sheller models are satisfactory. Based on the shelling capacity and economic returns these models are suitable for large farm holdings and custom-hire service.

- Farida (SBC), Rahman (SBC) and Uttaran (SBC) models have higher shelling capacity and have higher benefit-cost ratios, Gross Margins (GM) and Net Margins (NM). Partial Budget (PB) analyses indicate net gain in favour of these models over low capacity models and appear as most beneficial for custom-hire service.

- Economic analysis suggest that hand sheller could be beneficial for very small farm holdings, Binimoy (SP) and Sarker (SP) models for small farm holdings and Farida (SBC), Rahman (SBC) and Uttaran (SBC) models for medium to large farm holdings and custom-hire service.

\section{REFERENCES}

CIMMYT Office in Bangladesh (2006). Maize whole family training. In: Food Security in Bangladesh: Improving Wheat, Maize and Papaya Production and Impacts of Arsenic Contamination. Project Annual Report for 2005-2006. pp. 31-44. 